\title{
ENCODING PROCESS IN DELAYED RECALL IMPAIRMENT AND RATE OF FORGETTING IN ALZHEIMER'S DISEASE
}

\author{
Jairo Degenszajn', Paulo Caramelli', Leonardo Caixeta ${ }^{1}$, Ricardo Nitrini ${ }^{1}$
}

\begin{abstract}
Objective: To assess the role of impaired encoding in learning and in delayed recall disturbances, and to evaluate the rate of forgetting in AD. Method: Fifteen AD patients with mild or moderate dementia and 15 normal matched controls were assessed with the Buschke Selective Reminding Test. Delayed recall was evaluated after 30 minutes and after 24 hours. Results: AD patients had a poorer performance across the six trials of the learning phase as well as in both delayed recall evaluations, with no difference between recall at 30 minutes and at 24 hours. Conclusion: Performance in the learning phase was as specific and almost as sensitive as the performance in delayed recall for $A D$ diagnosis. Encoding impairment was responsible for poorer learning and rapid displacement of previous learned material in the $A D$ group. Finally, we did not find a higher rate of forgetting in $A D$ patients.
\end{abstract}

KEY WORDS: Alzheimer's disease, memory, encoding, learning, delayed memory, rate of forgetting.

\begin{abstract}
Comprometimento da codificação na deficiência de memória tardia e taxa de esquecimento na doença de Alzheimer

Objetivo: Investigar o papel do distúrbio da codificação nas deficiências de aprendizado e de memória e avaliar a taxa de esquecimento na doença de Alzheimer (DA). Método: Quinze pacientes com DA leve e moderada e 15 controles normais pareados foram avaliados pelo teste de memória seletiva de Buschke. A memória tardia foi avaliada depois de 30 minutos e depois de 24 horas. Resultados: Os pacientes com DA apresentaram desempenho inferior no aprendizado e na memória tardia. A taxa de esquecimento entre 30 minutos e 24 horas não foi diferente entre pacientes e controles. Conclusão: 0 desempenho na fase de aprendizado mostrou-se tão específico e quase tão sensível quanto o desempenho na memória tardia para o diagnóstico da DA. O distúrbio da codificação foi considerado responsável pelo distúrbio de aprendizado na DA. Após a memorização, o esquecimento não foi mais pronunciado na DA, nas primeiras 24 horas.
\end{abstract}

PALAVRAS-CHAVE: doença de Alzheimer, memória, codificação, aprendizado, memória tardia, taxa de esquecimento.

Memory impairment is the earliest and most prevalent symptom in Alzheimer's disease $(A D)^{1,2}$. The early involvement of the entorhinal cortex and CA1 of the hippocampus in $A D^{3,4}$ supports the observed decline in episodic memory even at the initial stages of the disease $\mathrm{e}^{5}$. It is well known that the performance of $A D$ patients is significantly poorer than that of normal elderly in tests that assess delayed recall of a list of items even a few minutes after its presentation $^{5}$. However, there is not as much information about differences in the rate of forgetting after these first few minutes. There are data that suggest that the rate of forgetting is faster in patients with bilat- eral temporal lobe lesion ${ }^{6}$ or dysfunction 7 . Corkin et al. ${ }^{8}$ reported a higher rate of forgetting in AD patients than in controls when they compared the delayed recall at 10 minutes and at 24 hours, although they did not find difference in an overall analysis at 72 hours. Kopelman ${ }^{9}$ found that AD patients did not display accelerated forgetting when assessed 24 hours after the learning phase.

We assessed verbal memory in AD patients and normal matched controls through the Free and Cued Selective Reminding Test (FCSRT) initially proposed by Buschke, with the inclusion of an assessment of delayed recall after 24 hours ${ }^{10-12}$. Through this para-

\footnotetext{
${ }^{1}$ Behavioral and Cognitive Neurology Unit, Department of Neurology, University of São Paulo, School of Medicine, São Paulo, Brazil. This paper is a part of the dissertation presented by the first author to the University of São Paulo, School of Medicine, for obtaining the degree of Master in Neurology. Jairo Degenszajn was supported by CNPq.
}

Received 3 April 2000, received in final form 24 October 2000. Accepted 1 November 2000. 
digm we intended to assess a) the encoding process using semantic cues; b) recall abilities with cues, when necessary, and c) the rate of forgetting of initially learned items. Since Craik and Lockhart's ${ }^{13}$ paper about the importance of the level of processing information in long-term storage, many others researchers have shown that the deepest an information is processed when encoded, the greatest is the possibility of retrieving it from long-term storage $\mathrm{e}^{11,12,15-17}$. The utilization of semantic cues during encoding stage and the same cues at retrieve increases the performance at delayed recall in both, $A D$ patients and healthy controls ${ }^{18}$.

\section{METHOD}

Fifteen patients (8 males and 7 females) with probable AD (NINCDS-ADRDA) ${ }^{19}$ and 15 age and educational matched controls ( 6 males and 9 females) were enrolled in this study ${ }^{20}$, after written consent. The characteristics of our sample are summarized in Table 1. According to the Clinical Dementia Rate $(C D R)^{21}, 11$ of the AD patients were considered as having mild disease and 4 were considered as having moderated disease. All the subjects were examined by an experienced neurologist and assessed by a comprehensive neuropsychological battery comprising tests for language, immediate memory, long-term memory, visuo-spatial and visuo-constructive skills, gnosis, praxis and planning, as previously described ${ }^{22}$. All AD patients were submitted to brain CT or MRI and to brain SPECT.

The FCSRT was applied, with modifications, as previously described ${ }^{1}$. Briefly, patients were presented to a white card with 16 black drawing line figures belonging to different semantic categories. Initially they were asked to identify and name all figures after the examiner had presented their semantic descriptors (p.ex.: which is the bird? For the owl). The objective of semantic descriptors presentation was to deepen the level of codification of infor-

Tabela 1. Sample characteristics: DAT patients versus healthy controls.

\begin{tabular}{lcccc}
\hline Variable & $\begin{array}{c}\text { AD patients } \\
(\mathrm{n}=15)\end{array}$ & $\begin{array}{c}\text { Controls } \\
(\mathrm{n}=15)\end{array}$ & $\mathrm{p}$-value & $\begin{array}{c}\text { Statistical } \\
\text { Test }\end{array}$ \\
\hline $\begin{array}{l}\text { Gender }(\mathrm{M} / \mathrm{F}) \\
8 / 7\end{array}$ & $6 / 9$ & & \\
$\begin{array}{l}\text { Age } \\
\text { (in years) }\end{array}$ & $70.2 \pm 9.0$ & $72.5 \pm 7.5$ & 0.50 & $\mathrm{M}-\mathrm{W}$ \\
$\begin{array}{l}\text { Education } \\
\text { (in years) }\end{array}$ & $10.5 \pm 7.5$ & $8.5 \pm 6.4$ & 0.73 & $\mathrm{M}-\mathrm{W}$ \\
$\begin{array}{l}\text { Score in } \\
\text { MMSE }\end{array}$ & $21.9 \pm 3.2$ & $28.4 \pm 1.2$ & 0.0001 & $\mathrm{M}-\mathrm{W}$ \\
\hline
\end{tabular}

$A D$, Alzheimer's disease; $p$ value, probability; M-W, Mann-Whitney; MMSE, mini mental state examination. mation. Then they were asked to immediately recall freely as many items as they were able to. After three minutes the examiner repeated the semantic descriptors for the items that were not freely recalled, as cues. After this first trial, five more trials followed and the subjects were presented to the same card between them and asked to identify and name only the items they had been unable to remind in the immediate preceding trial, again after the descriptor presentation. The delayed recall was performed 30 minutes and 24 hours after the sixth trial. In these moments the card was not re-presented and the cues were given only for those items not freely recalled. We used the sum of the free (SumFR) and total (free plus cued) recall (SumTR) across the six trials as a measure of learning ability. The total recall at the sixth trial was chosen to be compared with the total recall at 30 minutes and 24 hours to analyze the rate of forgetting.

Statistical analysis: The analysis of one variable between both groups were assessed by the Mann-Whitney test. The Friedman's test was used for an overall analysis of the loss of information across the three studied periods. The within-group analysis of loss of items between different blocks was assessed by the Dunn's test $(\alpha=0.05)$. The cutoff scores used to determine specificity and sensibility of the variables in differentiating both groups were based on the mean scores of controls minus two standard deviation.

\section{RESULTS}

AD patients performed significantly poorer than controls on all measures concerning their learning ability, delayed recall and cue utilization, as it's summarized in Table 2.

Table 2. FCSRT performance of AD patients versus healthy controls.

\begin{tabular}{lcccc}
\hline Variable & $\begin{array}{c}\text { AD patients } \\
(\mathrm{n}=15)\end{array}$ & $\begin{array}{c}\text { Controls } \\
(\mathrm{n}=15)\end{array}$ & $\mathrm{p}$ Value & $\begin{array}{c}\text { Statistical } \\
\text { Test }\end{array}$ \\
\hline SumFR & $33.0 \pm 18.5$ & $79.1 \pm 8.0$ & 0.0001 & $\mathrm{M}-\mathrm{W}$ \\
SumTR & $66.8 \pm 21.3$ & $95.3 \pm 0.7$ & 0.0001 & $\mathrm{M}-\mathrm{W}$ \\
$\begin{array}{l}\text { Utilization of } \\
\text { cues given }\end{array} \quad 59,6 \%$ & $97,1 \%$ & 0.001 & $\mathrm{M}-\mathrm{W}$ \\
$\begin{array}{l}\text { TR in the } \\
6^{\text {th }} \text { trial }\end{array}$ & $12.06 \pm 3.75$ & $16.0 \pm 0$ & 0.0001 & $\mathrm{M}-\mathrm{W}$ \\
$\begin{array}{l}\text { TR after } \\
\text { 30 min. }\end{array}$ & $8.3 \pm 4.8$ & $16.0 \pm 0$ & 0.0001 & $\mathrm{M}-\mathrm{W}$ \\
$\begin{array}{l}\text { TR after } \\
\text { 24 hours }\end{array}$ & $8.2 \pm 4.7$ & $16.0 \pm 0$ & 0.0001 & $\mathrm{M}-\mathrm{W}$ \\
\hline
\end{tabular}

FCSRT, free and cued selective reminding test; $A D$, Alzheimer's disease; SumFR, sum of free recall; SumTR, sum of total recall (free plus cued); TR, total recall; $p$, probability; M-W, MannWhitney. 
The mean of SumFR was $33.0 \pm 18.5$ for AD patients and 79.1 \pm 8.0 for controls $(p<0.0001)$. The mean of SumTR was $66.8 \pm 21.3$ for AD patients and $95.3 \pm 0.7$ for controls $(p<0.0001)$. The learning scores (SumFR and SumTR) were able to differentiate both groups with a sensitivity of $93.3 \%$ and specificity of $100 \%$. In order to compare the benefit that both groups had with cues at recall we computed the mean percentage of hits after cues presentation. In this way for the control group we could observe a mean of $97.1 \%$ of utilization of all cues given, whilst patients benefited from $59.6 \%$ after cues $(p<0.001)$.

The next results concern the rate of forgetting of previous learned information 30 minutes and 24 hours after the sixth trial. In the sixth trial of learning phase the mean of total recall (free plus cued) was $16.0 \pm 0$ for controls and $12.06 \pm 3.75$ for $A D$ patients $(p<0.0001)$. The mean total delayed recall after 30 min was $16.0 \pm 0$ for controls and $8.3 \pm 4.8$ for $A D$ patients, and at 24 hours it was $16.0 \pm 0$ and $8.2 \pm 4.7$, respectively $(p<0.0001)$. The delayed measures, either at 30 min or 24 hours, were highly sensitive $(100 \%)$ and specific (100\%) in differentiating both groups. Any statistical correlation between both groups concerning with rate of forgetting was discouraged as the control group performed at the ceiling in the three studied periods. Nevertheless, it was possible to observe an overall significant loss of information from the sixth trial to $30 \mathrm{~min}$ and 24 hours $(12.06,8.3$, and 8.2; $p<0.01)$ in AD patients, though, no significant differences could be observed comparing the mean of items recalled 30 minutes and 24 hours after the sixth trial $(8.3$ and 8.2 , respectively; $p>0.05$ ).

\section{DISCUSSION}

We found that scores of learning ability are as specific as delayed recall scores in differentiating $A D$ patients from elderly controls, although the sensibility of delayed recall is superior than learning ability (100\% e $93,3 \%$, respectively). This observation was also reported by Peterson et al. ${ }^{1}$, and it poses a theoretical question: In which point can we identify a disruption in the memory processes and what does remain intact in $A D$ ?

Our results point to a main impairment in the encoding process. The group of patients was not able to adequately encode information even when semantic descriptors were used to increase the depth of processing and this was clear when we analyzed their poor performance in the SumTR across the six trials. On the other hand, as AD patients were less benefited by cues than controls during recall, access impairment probably was not the main responsible for their failures in the six trials of the list learning. We did not analyze the benefit that patients had with cues in a within-group analysis, between SumTR and SumFR. However, their benefit was significantly lower than the controls. This conclusion also helps us to understand the findings concerning the loss of information and the rate in which it occurred.

Our results show that there was a loss of information when we compared the amount of items recalled at the sixth trial of the learning phase with those of the delayed phases (30 minutes and 24 hours) and that the decaying was significant only in the first 30 minutes, without additional loss from this moment to the next assessment at 24 hours. In our opinion, this pattern is in agreement with an encoding impairment, since those items not properly encoded were easily displaced from the transitory store in the hippocampus and not consolidated into a long-term storage. On the other hand, those items that were adequately encoded gained access and could be recalled from the long-term storage. Why some items could be deeply encoded and others could not may reflect a semantic impairment and a question of typicality of the chosen items.

We did not assess the typicality of items used in our test and, to our knowledge, this information is not available in Brazilian Portuguese. Two features were observed in our work, but not deeply studied and that could be of interest in this issue: a) all the subjects assessed, including those with $A D$, were able to name and identify all the figures when first presented to them, demonstrating that these figures belong to their lexical-semantic knowledge and b) $A D$ patients made more semantic errors during the test, mainly of subordinate class. What has called our attention was that, very often, the same intrusions were consistently recalled by patients throughout the test, but were not computed as hints. This finding suggests us that patients were able to learn their own list, that was not exactly the one we presented to them, demonstrating that they did not seem to be able to semantically encode some of the items, substituting them by others of the same category, but maybe of more typicality.

Finally, delayed recall scores after 30 minutes and after 24 hours were not statistically different in $A D$ patients, giving support to the hypothesis that accelerated forgetting is not a feature of AD. 


\section{REFERENCES}

1. Peterson RC, Smith GE, Ivnik RJ, Kokmen E, Tangalos EG. Memory function in very early Alzheimer's disease. Neurology 1994;44:867-872.

2. Rubin EH, Morris JC, Grant EA, Vendegna T. Very mild senile dementia of the Alzheimer type. Arch Neurol 1989;46:379-382.

3. Braak H, Braak E, Tilmazer D, De Vos RAI, Jansen ENH, Bohl J. Pattern of brain destruction in Parkinson's and Alzheimer's diseases. J Neural Transm 1996;103:455-490.

4. Hyman BT, Van Hoesen, GW, Damasio AR. Memory-related neural systems in Alzheimer's disease: an anatomic study. Neurology 1990;40:1721-1730.

5. Welsh K, Butters N, Hughes J, Mohs R, Heyman A. Detection of abnormal memory decline in mild cases of Alzheimer's disease: using CERAD neuropsychological measures. Arch Neurol 1991;48:278-281.

6. Huppert FA, Piercy M. Normal and abnormal forgetting in organic amnesia: effect of locus of lesion. Cortex 1979;15:385-390.

7. Squire LR. Two forms of human amnesia: an analysis of forgetting. J Neurosci 1981;1:635-640.

8. Corkin S, Growdon JH, Nissen MJ, Huff FJ, Freed DM, Sagar HJ. Recent advances in the neuropsychological study of Alzheimer's disease. In Wurtman RJ, Corkin S, Growdon, JH. Alzheimer's disease: advances in basic research and therapies, Cambridge, Massachusetts: Center for Brain Sciences and Metabolism Trust, 1984;75-93.

9. Kopelman MD. Multiple memory deficits in Alzheimer-type dementia: implications for pharmacotherapy. Psychol Med 1985;15:527 541.

10. Buschke H. Selective reminding for analysis of memory and learning. J Verbal Learn Verbal Behav 1973;12:543-550.

11. Buschke H, Sliwinski MJ, Kuslansky G, Lipton RL. Diagnosis of early dementia by the double memory test: encoding specificity improves diagnostic sensitivity and specificity. Neurology 1997;48:989-997.
12. Grober E, Buschke H, Crystal H, Bang S, Dresner R. Screening for dementia by memory testing. Neurology 1988;38:900-903.

13. Craik FIM, Lochart R. Levels of processing: a framework for memory research. J Verbal Learn Verbal Behav 1972;11:671-684.

14. Bird M, Luszcz M. Encoding specificity, depth of processing and cued recall in Alzheimer's disease. J Clin Exper Neuropsychol 1991;13:508520.

15. Herlitz A, Adolfsson R, Bäckman L, Nilsson LG. Cue utilization following different forms of encoding in mild, moderately and severely demented patients with Alzheimer's disease. Brain Cognition 1991;15:119-130.

16. Tuokko H, Crockett D. Cued recall and memory disorders in dementia. J Clin Exper Neuropsychol 1989;11:278-294.

17. Tuokko H, Vernon-Wilkinson R, Weir J, Beattie BL. Cued recall and early identification of dementia. J Clin Exper Neuropsychol 1991;13:871-879.

18. Bird M, Luszcz M. Enhancing memory performance in Alzheimer's disease: acquisition assistance and cue effectiveness. J Clin Exper Neuropsychol 1993;15:921-932.

19. McKhann G, Drachman D, Folstein M, Katzman R, Price D, Stadlan EM. Clinical diagnosis of Alzheimer's disease: report of the NINCDSADRDA work group . Neurology 1984;34:939-944.

20. Folstein MF, Folstein SE, McHugh PR. "Mini-mental state": a practical method for grading the cognitive state of patients for the clinician. J Psychiatr Res 1975;12:189-198.

21. Hughes CP, Berg L, Danziger WL, Coben LA, Martin RL. A new clinical scale for the staging of dementia. Br J Psychiatry 1982;140:566-572.

22. Degenszajn J. Avaliação da memória de longa-duração, recente e tardia, na doença de Alzheimer. Dissertação de Mestrado, à Faculdade de Medicina da Universidade de São Paulo. São Paulo, 1998. 